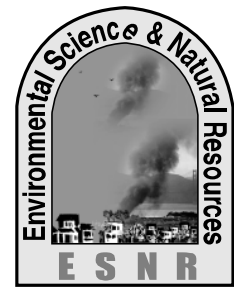

J. Environ. Sci. \& Natural Resources, 7(1): 7 - 11, 2014

ISSN 1999-7361

\title{
Effect of Phosphorus And Sulphur on Yield of Brri Dhan 57
}

\author{
M. H. Uddin' ${ }^{1}$ K. M. Rahman', M. Z. Rahman' ${ }^{2}$, Z. Alam ${ }^{3}$ and M. A. Salam ${ }^{4}$ \\ ${ }^{1}$ Department of Environmental Science, ${ }^{2}$ Department of Agricultural Extension Education \\ ${ }^{3}$ Department of Agroforestry, ${ }^{4}$ Department of Agricultural Chemistry, \\ Bangladesh Agricultural University, Mymensingh
}

\begin{abstract}
An experiment was conducted during the period from July, 2011 to December, 2011 to on the performance study of rice regarding to growth, yield and yield contributing characters of rice BRRI dhan 57 under the AEZ-28. The two factors experiment consists with four levels of Phosphorus (P) viz. $\mathrm{P}_{0}$ : without Phosphorus (control), $\mathrm{P}_{1}: 20 \mathrm{~kg} \mathrm{ha}^{-1}, \mathrm{P}_{2}: 40 \mathrm{~kg} \mathrm{ha}^{-1}$ and $\mathrm{P}_{3}: 60 \mathrm{~kg} \mathrm{ha}^{-1}$ and four levels of Sulphur viz. $\mathrm{S}_{0}$ : without Sulphur (control), $\mathrm{S}_{1}: 10 \mathrm{~kg} \mathrm{ha}^{-1}, \mathrm{~S}_{2}: 20 \mathrm{~kg} \mathrm{ha}^{-1}$ and $\mathrm{S}_{3}: 30 \mathrm{~kg} \mathrm{ha}^{-1}$. The result obtained from the study, it was found that all the traits were statistically significant due to Phosphorus whereas $40 \mathrm{~kg} \mathrm{P} \mathrm{ha}^{-1}$ recorded the tallest plant $(109.70 \mathrm{~cm})$ at harvest and maximum tillers hill ${ }^{-1}(17.58)$ at 85 DAT. Phosphorus @ $40 \mathrm{~kg} \mathrm{ha}^{-1}$ also recorded the greater results on effective tillers hill ${ }^{-1}(13.67)$, panicle length $(22.04 \mathrm{~cm})$, filled grains panicle ${ }^{-1}(138.60), 1000$-grain weight $(30.75 \mathrm{~g})$, weight of grain, straw and biological yield 5.12, 8.39 and $13.51 \mathrm{t} \mathrm{ha}^{-1}$, respectively and harvest index $(37.85 \%)$ at harvest while without phosphorus obtained the lower results on the above. In case of Sulphur, all the traits were significant except plant height at 55, 85 DAT and at harvest, filled grains panicle ${ }^{-1}$ and 1000-grain weight whereas $20 \mathrm{~kg} \mathrm{~S}^{-1}$ obtained the tallest plant $(109.40 \mathrm{~cm})$ at harvest and maximum tillers hill ${ }^{-1}$ (16.28) at 85 DAT. The maximum effective tillers hill ${ }^{-1}$ (12.12), longest panicle (21.35), higher weight of grain, straw and biological yield 4.75, 8.08 and $12.82 \mathrm{t} \mathrm{ha}^{-1}$, respectively and harvest index (36.90\%) were taken in $20 \mathrm{~kg} \mathrm{~S}$ $\mathrm{ha}^{-1}$ at harvest. It was also observed the minimum non effective tillers hill ${ }^{-1}(2.83)$ and unfilled grains panicle ${ }^{-1}(12.04)$ whereas all the Sulphur levels were produced statistically similar filled grains panicle ${ }^{-1}$ and 1000-grain weight at harvest due to non significant variation. The present findings obviously recommended that $40 \mathrm{~kg} \mathrm{P} \mathrm{ha}^{-1}$ or $20 \mathrm{~kg} \mathrm{~S}^{-1}$ singly or their interactions would be optimum level for getting the higher production of BRRI dhan 57.
\end{abstract}

Key Words: BARI Dhan 57, Phosphorus, Sulphur, Yield

\section{Introduction}

Rice (Oryza sativa L.) is the dominant staple food for many countries in Asia and Pacific, South and North America as well as Africa (Mobasser et al., 2007). It is also the most important food crop and a major food grain for more than a third of the world population (Zhao et al., 2011). In Bangladesh, during the year 2010-2011, rice covered an area of 28.5 thousand acres with a production of 33.5 million $\mathrm{M}$ tons while the average yield of rice in Bangladesh is around 1.2 thousand tons per acres whereas the transplant aman rice covers the largest area of 13951 acres $(48.97 \%)$ with a production of 12792 thousand $\mathrm{M}$ tons rice grain $(38.14 \%)$ and the average yield is about $971 \mathrm{~kg} \mathrm{ha}^{-1}$ in Bangladesh in 2010-11 (BBS, 2012). Fertilizer is very important input for intensive rice production. The profitability of rice production systems depends on yield and input quantities. So the appropriate fertilizer input that is not only for getting high grain yield but also for attaining maximum profertility (Khuang et al, 2008). Phosphorus fertilizer is a major essential plant nutrient and key input for increasing crop yield (Dastan et al., 2012; Alinajoati Sisie and Mirshekari, 2011; Alam et al., 2009). It was also important for the phosphorus accumulation in cultivated soils is a concern for non-point environmental pollution and for efficiency of phosphorus resources becouse of excessive phosphorus input (Li et al., 2010). Phosphorus deficit is a most important restrictive factor in plant growth and recognition of mechanisms that increase plant phosphorus use efficiency is important (Alinajoati Sisie \& Mirshekari, 2011). So, the appropriate fertilizer input that is not only for getting high grain yield but also for attaining maximum profitability (Khuang et al, 2008). Sulphur (S) is another essential macronutrient and it plays a vital role in the plant system and its deficiency in Bangladesh was first detected in rice at BRRI farm at Joydebpur in 1976. In recent years, $S$ deficiency has been receiving much attention as a major limiting factor for wetland rice. For rice cultivation, next to nitrogen, $\mathrm{S}$ application is very important. So, in fertilizer schedule, it is commonly included (Islam et al., 2009). So, it is needed to pay more attention to conduct more research with appropriate dose of $\mathrm{S}$ fertilizer in rice. From the above aspects, it is appeared that the cultivation or rice is the most effective means to increase the yield per unit area by applying the proper doses of $\mathrm{P}$ and $\mathrm{S}$ fertilizers. Considering above points, the present study was undertaken to achieve the following objectives: to find out the appropriate doses of $\mathrm{P}$ and $\mathrm{S}$ regarding to proper growth and higher production of BRRI dhan 57 , to select the most advantigious treatment combination of $\mathrm{P}$ and $\mathrm{S}$ fertilizers concerning to growth and yield of BRRI dhan 57. 


\section{Materials and Methods}

This chapter describes the experimental aspects of the study. The experiment was conducted at the research farm of the period from July 2011 to December 2011 (Kharif II) to judgment out the most appropriate singly or combined doses of Phosphorus (P) and Sulphur (S) on the aspect of better growth, higher production and yield and superior quality of grain and straw of studied rice cultivar cv. BRRI dhan 57. The experimental area is situated in the sub-tropical climatic zone and characterized by heavy rainfall during the months of April to September (Kharif Season) and scanty rainfall during the rest period of the year (Biswas, 1987).

\section{Plant materials (variety)}

The seeds of BRRI dhan 57 were used as planting materials which was collected from the Bangladesh Rice Research Institute (BRRI), Joydebpur, Gazipur-1701.

\section{Experimental design and layout:}

The experiment consisted of four doses of Phosphrus (P) and four doses of Sulphur (S) and was laid out a two factors split-plot (Phosphorus in the main plot and Sulphur in the sub-plot) in Randomized Complete Block Design (RCBD) with three replications. The size of plot was $4.0 \times 3.0 \mathrm{~m}$ $\left(12 \mathrm{~m}^{2}\right)$ where block to block and plot to plot distance was 0.75 and $0.5 \mathrm{~m}$, respectively. Row to row and plant to plant distance were also 20 and 20 $\mathrm{cm}$, respectively, in each plot. So, the total plots were $48($ P $4 \times$ S $4 \times$ Replication 3$)$.

\section{Crop Management,}

Seed collection, seed sprouting, preparation of seedling nursery, seed sowing, land preparation for transplanting, fertilizer application, uprooting of seedlings, transplanting of seedlings, intercultural operations, weeding, sampling and data collection, harvest and post harvest operations were done.

\section{Parameters studied}

1000 grain weight $(\mathrm{g})$, grain yield $\left(\mathrm{t} \mathrm{ha}^{-1}\right)$, straw yield $\left(\mathrm{t} \mathrm{ha}^{-1}\right)$, biological yield $\left(\mathrm{t} \mathrm{ha}^{-1}\right)$, harvest index (\%) were studies.

\section{Statistical analyses}

Data recorded for yield and yield contributing characters and seed quality characters were compiled and tabulated in proper form for statistical analyses. Analysis of variance was done with the help of MSTAT-C computer package programme developed by Russel (1986). The mean differences among the treatments were evaluated with DMRT test (Gomez and Gomez, 1984).

\section{Results and Discussion}

The present research work was to investigate the effect of Phosphorus and Sulphur on the performance of growth and yield of rice cv. BRRI dhan 57 under the Agro-ecological zone of "The Modhupur Tract", AEZ-28. The results on yield and yield attributing characters of BRRI dhan 57 have been presented in Tables 1 to 4 .

\section{Interaction effect of Phosphorus and Sulphur}

The data on unfilled grains panicle ${ }^{-1}$ showed significant difference among the interaction effect between Phosphorus and Sulphur (Table 1). The unfilled grains panicle ${ }^{-1}$ varied from 7.87 to 16.27 due to interaction effect of Phosphorus and Sulphur fertilizers. The minimum number of unfilled grains panicle $^{-1}$ (16.27) was found in interaction of $0 \mathrm{~kg} \mathrm{P}$ $\mathrm{ha}^{-1}$ and $10 \mathrm{~kg} \mathrm{~S} \mathrm{ha}^{-1}$ which was followed by the interaction effects of both $0 \mathrm{~kg} \mathrm{P}$ and $\mathrm{S} \mathrm{ha}^{-1}$ (15.85) and $0 \mathrm{~kg} \mathrm{P} \mathrm{ha}^{-1}$ and $30 \mathrm{~kg} \mathrm{~S} \mathrm{ha}^{-1}$ (16.02) whereas interaction effect of $0 \mathrm{~kg} \mathrm{P} \mathrm{ha}^{-1}$ and $10 \mathrm{~kg} \mathrm{~S} \mathrm{ha}^{-1}$ and $0 \mathrm{~kg} \mathrm{P} \mathrm{ha}^{-1}$ and $30 \mathrm{~kg} \mathrm{~S} \mathrm{ha}^{-1}$ were statistically identical to produced unfilled grains panicle ${ }^{-1}$. On the other hand, interaction effect between $40 \mathrm{~kg} \mathrm{P}$ $\mathrm{ha}^{-1}$ and $20 \mathrm{~kg} \mathrm{~S} \mathrm{ha}{ }^{-1}$ obtained the minimum number of unfilled grains panicle ${ }^{-1}$ (7.87) which was statistically differed from other interactions (Table 1).

\section{Effect of phosphorus}

Application of phosphorus as soil and foliar application at various levels showed significant variation in respect of harvest index in the present study (Table 2). From the Table 2, it was appeared that the highest harvest index $(37.85 \%)$ was found in $40 \mathrm{~kg} \mathrm{P} \mathrm{ha}{ }^{-1}$ in case of the higher yield of grain and straw as well as maximum biological yield were found under this treatment. Similarly, the control treatment observed the lowest harvest index $(34.82 \%)$ due to its lowest yield of grain and straw as well as minimum biological yield were achieved in this treatment. Another treatment also showed significant effect while harvest index of 36.03 and $35.47 \%$ were found in 20 and $60 \mathrm{~kg} \mathrm{P} \mathrm{ha}{ }^{-1}$, respectively (Table 2 ). These results revealed that the variation in harvest index was found due the variation in phosphorus levels. These were similar to Yosef (2013b) whereas they found that the maximum harvest index was (47.92) observed for $90 \mathrm{~kg} \mathrm{ha}^{-1}$ phosphorus fertilizer and minimum of that was (47.79) obtained for (control) $0 \mathrm{~kg} \mathrm{ha}^{-1}$ phosphorus fertilizer. 
Table 1. Interaction effect between Phosphorus and Sulphur on number of effective and non effective tillers hill $^{-1}$, length of panicle and number of filled and unfilled grains panicle ${ }^{-1}$ production at harvest

\begin{tabular}{|c|c|c|c|c|c|c|}
\hline $\begin{array}{c}\text { Phosphorus } \\
\text { levels } \\
\left.\mathrm{ha}^{-1}\right)\end{array}$ & $\begin{array}{c}\text { Sulphur } \\
\text { levels }(\mathrm{kg} \\
\left.\mathrm{ha}^{-1}\right) \\
\end{array}$ & $\begin{array}{c}\text { Number of } \\
\text { effective tillers } \\
\text { hill }^{-1} \\
\end{array}$ & $\begin{array}{c}\text { Number of non } \\
\text { effective tillers } \\
\text { hill }^{-1} \\
\end{array}$ & $\begin{array}{c}\text { Length of } \\
\text { panicle }(\mathrm{cm})\end{array}$ & $\begin{array}{l}\text { Number of filled } \\
\text { grains panicle }^{-1}\end{array}$ & $\begin{array}{l}\text { Number of unfilled } \\
\text { grains panicle }^{-1}\end{array}$ \\
\hline \multirow[t]{4}{*}{0} & 0 & $7.167 \mathrm{o}$ & $3.833 \mathrm{c}$ & $18.70 \mathrm{k}$ & $108.8 \mathrm{~h}$ & $15.85 \mathrm{ab}$ \\
\hline & 10 & $7.833 \mathrm{~m}$ & $3.900 \mathrm{~b}$ & $19.49 \mathrm{i}$ & $109.4 \mathrm{~h}$ & $16.27 \mathrm{a}$ \\
\hline & 20 & $9.633 \mathrm{~h}$ & $3.700 \mathrm{~d}$ & $19.93 \mathrm{~g}$ & $112.8 \mathrm{~g}$ & $15.58 \mathrm{~b}$ \\
\hline & 30 & $7.267 n$ & $3.967 \mathrm{a}$ & $19.18 \mathrm{j}$ & $108.9 \mathrm{~h}$ & $16.02 \mathrm{ab}$ \\
\hline \multirow[t]{4}{*}{20} & 0 & $9.100 \mathrm{j}$ & $3.300 \mathrm{~h}$ & $20.02 \mathrm{fg}$ & $117.6 \mathrm{e}$ & $13.55 \mathrm{fg}$ \\
\hline & 10 & $9.800 \mathrm{~g}$ & $3.333 \mathrm{~h}$ & $20.48 \mathrm{e}^{\circ}$ & $118.2 \mathrm{e}$ & 13.97 def \\
\hline & 20 & $11.97 \mathrm{e}$ & $2.767 \mathrm{j}$ & $21.42 \mathrm{c}$ & $130.2 \mathrm{c}$ & $11.62 \mathrm{~h}$ \\
\hline & 30 & $9.200 \mathrm{i}$ & $3.433 \mathrm{~g}$ & $20.17 \mathrm{f}$ & $117.8 \mathrm{e}$ & $13.72 \mathrm{ef}$ \\
\hline \multirow[t]{4}{*}{40} & 0 & $12.80 \mathrm{~d}$ & 2.3671 & $21.43 \mathrm{c}$ & $137.4 \mathrm{~b}$ & $8.450 \mathrm{i}$ \\
\hline & 10 & $13.43 \mathrm{~b}$ & $2.467 \mathrm{k}$ & $21.89 \mathrm{~b}$ & $138.0 \mathrm{~b}$ & $8.867 \mathrm{i}$ \\
\hline & 20 & $15.53 \mathrm{a}$ & $1.967 \mathrm{~m}$ & $23.26 \mathrm{a}$ & $141.4 \mathrm{a}$ & $7.867 \mathrm{j}$ \\
\hline & 30 & $12.90 \mathrm{c}$ & $2.500 \mathrm{k}$ & $21.58 \mathrm{c}$ & $137.6 \mathrm{~b}$ & $8.617 \mathrm{i}$ \\
\hline \multirow[t]{4}{*}{60} & 0 & 8.4001 & $3.500 \mathrm{f}$ & $19.70 \mathrm{~h}$ & $114.5 \mathrm{fg}$ & 14.15 cde \\
\hline & 10 & $9.133 \mathrm{j}$ & $3.500 \mathrm{f}$ & $20.16 \mathrm{f}$ & $115.0 \mathrm{f}$ & $14.57 \mathrm{c}$ \\
\hline & 20 & $11.33 \mathrm{f}$ & $2.900 \mathrm{i}$ & $20.78 d$ & $123.6 \mathrm{~d}$ & $13.08 \mathrm{~g}$ \\
\hline & 30 & $8.500 \mathrm{k}$ & $3.633 \mathrm{e}$ & $19.85 \mathrm{gh}$ & $114.6 \mathrm{fg}$ & $14.32 \mathrm{~cd}$ \\
\hline \multicolumn{2}{|c|}{ Level of significance } & $*$ & $* *$ & $* *$ & $* *$ & $* *$ \\
\hline \multicolumn{2}{|c|}{$\operatorname{LSD}_{(0.05)}$} & 0.05329 & 0.05329 & 0.1685 & 1.975 & 0.4971 \\
\hline \multicolumn{2}{|c|}{ SX value } & 0.01826 & 0.01826 & 0.05774 & 0.6765 & 0.1703 \\
\hline \multicolumn{2}{|c|}{$\mathrm{CV}(\%)$} & 1.03 & 1.14 & 0.5 & 0.96 & 2.29 \\
\hline
\end{tabular}

Figures followed by same letter(s) are statistically similar as per DMRT at 5\%

$\mathrm{LSD}=$ Least significant difference; $\mathrm{CV}=\mathrm{Co}-\mathrm{efficient}$ of variation; * $=$ Significant at $5 \%$ level of probability

Table 2. Main effect Phosphorus on 1000-grain weight, yield characters and HI at harvest

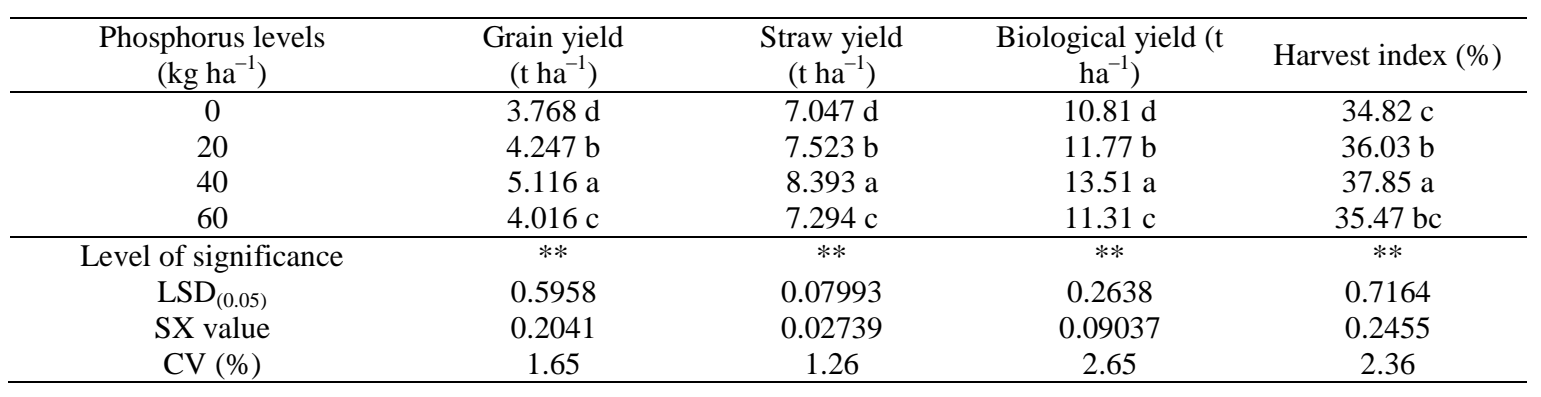

Figures followed by same letter(s) are statistically similar as per DMRT at 5\%

$\mathrm{LSD}=$ Least significant difference; $\mathrm{CV}=\mathrm{Co}-$ efficient of variation; *= Significant at $5 \%$ level of probability

\section{Effect of Sulphur}

Harvest index represent comparative yield performance between grain and straw yield. It was also indicate the percent grain yield on the basis of biological yield. The data on harvest index was significantly influenced by the Sulphur application in this study. Sulphur @ $20 \mathrm{~kg} \mathrm{ha}^{-1}$ recorded the highest harvest index (36.90\%). The lowest harvest index $(35.45 \%)$ was observed in without Sulphur which was statistically similar to $30 \mathrm{~kg} \mathrm{~S} \mathrm{ha}{ }^{-1}$ $(35.71 \%)$. However, $10 \mathrm{~kg} \mathrm{~S}^{-1}$ obtained harvest index of $36.11 \%$ which was statisticaly close to both higher and lower harvest index in this study (Table 3). These results revealed that harvest index differed significantly due to the significant differences of the studied Sulphur application and also the variation of grain and straw yield as well as biological yield. 
Table 3. Main effect Sulphur on 1000-grain weight, yield characters and HI at harvest

\begin{tabular}{|c|c|c|c|c|}
\hline $\begin{array}{l}\text { Sulphur levels } \\
\quad\left(\mathrm{kg} \mathrm{ha}^{-1}\right)\end{array}$ & $\begin{array}{l}\text { Grain yield } \\
\left(\mathrm{t} \mathrm{ha}^{-1}\right)\end{array}$ & Straw yield & Biological yield $\left(\mathrm{t} \mathrm{ha}^{-1}\right)$ & Harvest index (\%) \\
\hline 0 & $3.958 \mathrm{c}$ & $7.177 \mathrm{c}$ & $11.14 \mathrm{~b}$ & $35.45 \mathrm{~b}$ \\
\hline 10 & $4.375 \mathrm{~b}$ & $7.713 \mathrm{~b}$ & $12.09 \mathrm{ab}$ & $36.11 \mathrm{ab}$ \\
\hline 20 & $4.745 \mathrm{a}$ & $8.075 \mathrm{a}$ & $12.82 \mathrm{a}$ & $36.90 \mathrm{a}$ \\
\hline 30 & $4.068 \mathrm{c}$ & $7.293 \mathrm{c}$ & $11.36 \mathrm{~b}$ & $35.71 \mathrm{~b}$ \\
\hline Level of significance & $* *$ & $* *$ & * & $*$ \\
\hline $\operatorname{LSD}_{(0.05)}$ & 0.1842 & 0.279 & 1.369 & 0.8405 \\
\hline SX value & 0.05323 & 0.08062 & 0.3955 & 0.2429 \\
\hline $\mathrm{CV}(\%)$ & 1.65 & 1.26 & 2.65 & 2.36 \\
\hline
\end{tabular}

Figures followed by same letter(s) are statistically similar as per DMRT at $5 \%$

$\mathrm{LSD}=$ Least significant difference; $\mathrm{CV}=\mathrm{Co}-$ efficient of variation; * $=$ Significant at $5 \%$ level of probability

\section{Interaction effect of Phosphorus and Sulphur}

Analysis of variance data regarding to harvest index was significantly influenced by the interaction effect of the studied Phosphorus and Sulphur fertilizers (Table 4). Table 4 indicated that the harvest index varied from 34.24 to $38.59 \%$ where the interaction treatment of $40 \mathrm{~kg} \mathrm{P} \mathrm{ha}^{-1}$ and $20 \mathrm{~kg} \mathrm{~S} \mathrm{ha}{ }^{-1}$ recorded the highest harvest index $(38.59 \%)$ which was closely followed by the interactions effect of $40 \mathrm{~kg} \mathrm{P} \mathrm{ha}{ }^{-1} \times 10 \mathrm{~kg} \mathrm{~S}^{-1}$ (37.83\%), $20 \mathrm{~kg} \mathrm{P} \mathrm{ha}^{-1} \times 20 \mathrm{~kg} \mathrm{~S} h a^{-1}(37.18 \%), 40$ $\mathrm{kg} \mathrm{P} \mathrm{ha}^{-1} \times 0 \mathrm{~kg} \mathrm{~S} h a^{-1}(37.39 \%)$ and $40 \mathrm{~kg} \mathrm{P} \mathrm{ha}^{-1} \times$ $30 \mathrm{~kg} \mathrm{~S} \mathrm{ha}^{-1}(37.58 \%)$ whereas $20 \mathrm{~kg} \mathrm{P} \mathrm{ha}^{-1} \times 20$

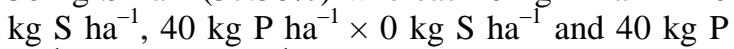
$\mathrm{ha}^{-1} \times 30 \mathrm{~kg} \mathrm{~S} \mathrm{ha}^{-1}$ were statistically identical. In contrast, the lowest harvest index $(34.24 \%)$ was recorded in both control fertilizers which was also closely followed by the maximum interactions of both fertilizers among the rest interaction effects. The variation in harvest index was found due to the variation yield of grain, straw and biological yield and also the variation in fertilizer levels.

Table 4. Interaction effect between Phosphorus and Sulphur on 1000-grain weight, yield characters and HI at harvest

\begin{tabular}{|c|c|c|c|c|c|c|}
\hline $\begin{array}{c}\text { P levels (kg } \\
\left.\mathrm{ha}^{-1}\right)\end{array}$ & $\begin{array}{c}\text { S levels (kg } \\
\left.\mathrm{ha}^{-1}\right)\end{array}$ & $\begin{array}{l}\text { Thousand grain weight } \\
\text { (g) }\end{array}$ & $\left.\begin{array}{c}\text { Grain yield }\left(\mathrm{t} \mathrm{ha}^{-}\right. \\
1\end{array}\right)$ & $\left.\begin{array}{c}\text { Straw yield }\left(\mathrm{t} \mathrm{ha}^{-}\right. \\
1\end{array}\right)$ & $\begin{array}{c}\text { Biological yield (t } \\
\left.\mathrm{ha}^{-1}\right)\end{array}$ & $\begin{array}{c}\text { Harvest index } \\
(\%)\end{array}$ \\
\hline \multirow[t]{4}{*}{0} & 0 & $25.88 \mathrm{i}$ & $3.497 \mathrm{k}$ & 6.7171 & 10.211 & $34.24 \mathrm{f}$ \\
\hline & 10 & 26.42 ghi & $3.914 \mathrm{gh}$ & $7.252 \mathrm{gh}$ & 11.17 ghij & $35.05 \mathrm{def}$ \\
\hline & 20 & $27.08 \mathrm{fgh}$ & $4.053 \mathrm{f}$ & $7.387 \mathrm{fg}$ & $11.44 \mathrm{fgh}$ & 35.44 def \\
\hline & 30 & $26.05 \mathrm{hi}$ & $3.607 \mathrm{jk}$ & $6.833 \mathrm{kl}$ & $10.44 \mathrm{kl}$ & 34.55 ef \\
\hline \multirow[t]{4}{*}{20} & 0 & $27.69 \mathrm{f}$ & $3.877 \mathrm{gh}$ & $7.093 \mathrm{hi}$ & 10.97 hijk & $35.33 \mathrm{def}$ \\
\hline & 10 & $28.23 \mathrm{ef}$ & $4.293 \mathrm{e}$ & $7.631 \mathrm{e}$ & $11.92 \mathrm{ef}$ & 36.00 cde \\
\hline & 20 & $29.48 \mathrm{~cd}$ & $4.833 \mathrm{c}$ & $8.160 \mathrm{c}$ & $12.99 \mathrm{c}$ & $37.18 \mathrm{abc}$ \\
\hline & 30 & $27.86 \mathrm{ef}$ & $3.987 \mathrm{fg}$ & $7.210 \mathrm{~h}$ & $11.20 \mathrm{ghi}$ & $35.60 \mathrm{def}$ \\
\hline \multirow[t]{4}{*}{40} & 0 & $30.22 \mathrm{bc}$ & $4.767 \mathrm{c}$ & $7.983 \mathrm{~d}$ & $12.76 \mathrm{~cd}$ & $37.39 \mathrm{abc}$ \\
\hline & 10 & $30.76 \mathrm{ab}$ & $5.185 \mathrm{~b}$ & $8.523 \mathrm{~b}$ & $13.71 \mathrm{~b}$ & $37.83 \mathrm{ab}$ \\
\hline & 20 & $31.63 \mathrm{a}$ & $5.637 \mathrm{a}$ & $8.967 \mathrm{a}$ & $14.60 \mathrm{a}$ & $38.59 \mathrm{a}$ \\
\hline & 30 & $30.39 \mathrm{bc}$ & $4.877 \mathrm{c}$ & $8.100 \mathrm{~cd}$ & $12.98 \mathrm{c}$ & $37.58 \mathrm{abc}$ \\
\hline \multirow[t]{4}{*}{60} & 0 & $27.16 \mathrm{fgh}$ & $3.693 \mathrm{ij}$ & $6.913 \mathrm{jk}$ & $10.60 \mathrm{jkl}$ & $34.83 \mathrm{def}$ \\
\hline & 10 & $27.69 \mathrm{f}$ & $4.109 \mathrm{f}$ & $7.447 \mathrm{f}$ & $11.56 \mathrm{fg}$ & $35.56 \mathrm{def}$ \\
\hline & 20 & $28.90 \mathrm{de}$ & $4.457 \mathrm{~d}$ & $7.787 \mathrm{e}$ & $12.24 \mathrm{de}$ & $36.39 \mathrm{bcd}$ \\
\hline & 30 & $27.32 \mathrm{fg}$ & $3.803 \mathrm{hi}$ & $7.030 \mathrm{ij}$ & $10.83 \mathrm{ijk}$ & $35.11 \mathrm{def}$ \\
\hline \multicolumn{2}{|c|}{ Level of sig. } & $*$ & $* *$ & $*$ & $*$ & $*$ \\
\hline \multicolumn{2}{|c|}{$\operatorname{LSD}_{(0.05)}$} & 1.025 & 0.1192 & 0.1599 & 0.5275 & 1.433 \\
\hline \multicolumn{2}{|c|}{ SX value } & 0.3512 & 0.04082 & 0.05477 & 0.1807 & 0.4909 \\
\hline \multicolumn{2}{|c|}{$\mathrm{CV}(\%)$} & 2.15 & 1.65 & 1.26 & 2.65 & 2.36 \\
\hline
\end{tabular}

Figures followed by same letter(s) are statistically similar as per DMRT at 5\%

$\mathrm{LSD}=$ Least significant difference; $\mathrm{CV}=\mathrm{Co}-\mathrm{efficient}$ of variation; $*=$ Significant at $5 \%$ level of probability

The results of the present study were obtained on various characteristics of yield and yield attributing traits of BRRI dhan 57 whereas all the studied characters were statistically significant at $5 \%$ level due to phosphorus application where 40 $\mathrm{kg} \mathrm{P} \mathrm{ha}^{-1}$ showed superior performance on them.
The result of plant height and tillers hill ${ }^{-1}$ were significantly increase with the advancement of study period while tillers production significantly decreased at harvest due to its mortality for maturity. Maximum tillers hill ${ }^{-1}$ was also observed in $20 \mathrm{~kg} \mathrm{~S} \mathrm{ha}^{-1}$ and minimum tillers hill ${ }^{-1}$ in control 
$\mathrm{S}$ at 85 DAT while it decreased at harvest. On the other hand, the maximum effective tillers hill ${ }^{-}$, longest panicle, higher weight of grain, straw and biological yield and harvest index were taken in 20 $\mathrm{kg} \mathrm{S} \mathrm{ha}^{-1}$ at harvest. Similarly, control $\mathrm{S}$ recorded the minimum effective tillers hill ${ }^{-1}$, shortest panicle , minimum yield of grain, straw and biological and lowest HI whereas statistically similar lower effective tillers hill ${ }^{-1}$, shortest panicle, lowest yield of grain, straw and biological and lowest HI

\section{References}

Alinajati, S. and Mirshekari, B. 2011. Effect of phosphorus fertilization and seed bio fertilization on harvest index and phoshorus use efficiency of wheat cultivars. J. Food, Agril. Environ., 9(2): 388-397.

BBS (Bangladesh Bureauo Statistics). 2012. Statistic Pocket Book of Bangladesh (20010-11). Bangladesh Bureau of Statistic Division, Govt. of the People's Republic of Bangladesh. p. 37.

Biswas, P.K. 1987. A study on the relative merits of mixed cropping under two levels of irrigations. M.Sc. Thesis. Department of Agronomy, Bangladesh Agricultural University, Mymensingh. p. 18.

Dastan, S.; Siavoshi, M.; Zakavi, D.; Ghanbaria, M. A.; Yadi, R.; Ghorbannia, D.E. and Nasiri, A.R. 2012. Application of nitrogen and silicon rates on morphological and chemical lodging related characteristics in rice (Oryza sativa L.) north of Iran. $J$. Agril. Sci., 4(6).

Gomez, K.A. and Gomez, A.A.1984. Statistical Procedures for Agricultural Research. $2^{\text {nd }}$ Edn. John Willey and Sons, New York. pp. 97-411.

Islam, M. R.; Shah, M.S. and Jahiruddin, M. 2009. Effects of different rates and sources of sulphur on the growth and yield of BRRI dhan30. Bangladesh Res. Pub. J., 2(1): 397- were also found in higher doses of S (30 kg S ha $\left.{ }^{-1}\right)$. However, $20 \mathrm{~kg} \mathrm{~S}^{-1}$ observed the minimum non effective tillers hill ${ }^{-1}$ and unfilled grains panicle ${ }^{-1}$ but maximum non effective tillers hill and unfilled grains panicle ${ }^{-1}$ were taken in $30 \mathrm{~kg} \mathrm{~S}^{-1}$ and 10 $\mathrm{kg} \mathrm{S} \mathrm{ha}{ }^{-1}$, respectively while all the $\mathrm{S}$ levels including control were produced statistically similar filled grains panicle ${ }^{-1}$ and 1000-grain weight at harvest due to non significant variation.

$$
\begin{aligned}
& 405 . \quad \text { (online available at: } \\
& \text { http://www.bdresearchpublications } \\
& \text {.com/admin/journal/upload/08045/08045.p } \\
& \text { df). }
\end{aligned}
$$

Khuang, T. Q.; Huan, T.T. and Hach, C.V. 2008. Study on fertilizer rates for getting maximum grain yield and profitability of rice production. Omonrice, 16: 93-99.

Li, J.; Gao, J. and Ma, Y. 2010 Phosphorus accumation in soil in rice cropping systems with chemical fertilizer application: modeling and validation. World congress of soil science, soil solutions for a changing world. 224227pp.

Mobasser, H.R.; Delarestaghi, M.M.; Khorgami, A.; Tari, D.B. and Pourkalhor, H. 2007. Effect of planting density on agronomical characteristics of rice (Oryza sativa L.) varieties in North of Iran. Pak. J. Biol. Sci., 10(18): 3205-3209.

Russel, D. F. 1986. MSTAT-C package programme. Crop and Soil Sci. Dept., Michigan State Univ., USA.

Yosef, T. S. 2013b. Effect of Nitrogen and Phosphorus Fertilizer on spikelet Structure and yield in rice (Oryza sativa L). Intl. J. Agril. Crop Sci., 5(11): 1204-1208.

Zhao, L.; Wu, L.; Wu, M. and Li, Y. 2011. Nutrient uptake and water use efficiency as affected by modified rice cultivation methods with irrigation. Paddy Water Environ., 9: 25-32. 